\title{
Factors causing stress among first-year students attending a nursing college in KwaZulu-Natal, South Africa
}

\author{
E M Langtree, ${ }^{1,2}$ MTech Nursing; A Razak, ${ }^{1} \mathrm{PhD} ;$ F Haffejee, ${ }^{3} \mathrm{PhD}$ \\ ${ }^{1}$ Department of Nursing, Faculty of Health Sciences, Durban University of Technology, South Africa \\ ${ }^{2}$ Port Shepstone Campus, KwaZulu-Natal College of Nursing, South Africa \\ ${ }^{3}$ Department of Basic Medical Sciences, Faculty of Health Sciences, Durban University of Technology, South Africa
}

Corresponding author: F Haffejee (firozah@dut.ac.za)

\begin{abstract}
Background. In South Africa (SA), there is a high failure rate of students in the first year of nursing and many drop out after this year, a precarious situation considering the shortage of professional nurses faced by the country. Academic success does not entirely comprise one's application of intellectual capacity. Other factors may affect academic success, which could lead to stress, in turn hindering students' academic potential.

Objectives. To determine the stressors experienced by first-year nursing students who attended a college of nursing in SA and to ascertain the stressrelieving mechanisms used by these students.

Methods. Student nurses $(n=248)$ at a college of nursing in KwaZulu-Natal Province, SA, were required to complete a quantitative questionnaire. Data were collected between September and November 2013.

Results. Long working hours, difficulty of academic work, poor study methods and family illness caused considerable stress. Family pressure to pay for necessities at home was also a factor that caused stress among the students. There was insufficient money to pay for textbooks for their studies. Stress-relieving mechanisms included playing with cell phones and socialising with friends. Lecturers, parents and fellow nursing students' friends were a source of support.

Conclusion. First-year nursing students experience a variety of stressors not directly related to their studies. Stress- and time-management workshops would be beneficial to these students. We also suggest that institutional support units be created to assist students in adjusting to the tertiary environment.
\end{abstract}

Afr J Health Professions Educ 2018;10(2):90-95. DOI:10.7196/AJHPE.2018.v10i2.993

In South Africa (SA), higher education students exhibit progressively poor success rates. ${ }^{[1]}$ The Council on Higher Education (CHE) observed that only $35 \%$ of all first-year entrants graduate within 5 years. ${ }^{[1]}$ In KwaZulu-Natal (KZN) Province, SA, the majority of nurses are trained at a college of nursing, which has satellite campuses throughout the province. ${ }^{[2]}$ There is, however, a high failure rate among these students, mostly in the first year of study. Because of academic failure, $22 \%$ of students leave the training programme after the first year ${ }^{[3]}-$ a precarious situation, considering the shortage of professional nurses faced by the country ${ }^{[4,5]}$ In an attempt to address this high attrition rate, the admission criteria for entry into the programme were increased, but this did not have a noticeable influence on the pass rate.

Students entering SA higher education institutions usually come from a wide range of cultural and social backgrounds, with resultant varying life experiences and educational opportunities, including different expectations, needs and academic potential. ${ }^{[6]}$ Academic success does not entirely consist of one's application of intellectual capacity. There are many other factors that directly or indirectly affect academic success. These include the transition from secondary school to university, student motivation, study methods, teaching strategies, interaction between students, academic and social systems of the university, cultural expectations, psychosocial factors and lack of finances. ${ }^{[7-10]}$ One or more of these factors could lead to stress, which could hinder academic potential by distracting students' focus from their studies. ${ }^{[11]}$

Research has shown that self-concept positively affects the success of nursing students' ability to manage anxiety and stress related to studying.
Specifically, if a student is confident in his/her ability and remains motivated, he/she is more likely to succeed academically, resulting in lower dropout rates. Whereas the overwhelming stress associated with test anxiety has a negative relationship with academic achievements, this could lead to a decrease in the academic success of students. ${ }^{[12]}$

The nursing programme also contains both intensive coursework and practical components at hospitals, which may become overwhelming and stressful with regard to a student's ability to cope with examinations. ${ }^{[12]}$ Attrition rates among nursing students remain high, irrespective of attempts by institutions to provide strategies such as selection in line with quality of students, and implementing student mentoring and tutoring.

It is unknown whether the stress factors that affect students attending a large university with many different faculties are different from those of students who attend smaller tertiary institutions that train them in one particular course only. In nursing, stress factors related to the clinical learning environment are well documented. ${ }^{[10,13,14]}$ The increased stress of nursing students is due to the simultaneous learning in both academic and clinical areas. This adds to the growing personal stressors experienced by these students. Stress negatively influences students, thus affecting their academic performance and course completion rates. ${ }^{[15]}$

Literature on stress that affects nursing students in small tertiary colleges in the early years of academic study is lacking. The objective of this study was to determine the stressors experienced by first-year nursing students who attended a college of nursing in SA. The study also ascertained the stress-relieving mechanisms used by these students. 


\section{Methods}

A quantitative descriptive survey design was used. Student nurses at a selected nursing college in KZN, who were either in the final stages of completing their first year of study or had done so in the previous semester, formed the target population $(N=524)$ for this study.

Using Cochrane's formula, a minimum of 222 participants were required for the sample population to achieve significant results at a $95 \%$ confidence level. As we anticipated a response rate of $\sim 80 \%, 267$ students were targeted. Five campuses from 8 of the 9 campuses that comprise the nursing college were chosen for the study by a ballot method. The campuses differed only with regard to geographical distribution, which allows for easy access to students from different parts of the province. The campus at which the principal investigator (EML) lectures, was excluded from the study. The criteria required for inclusion in the study were: first-year nursing students enrolled for a minimum of 7 months at the college, who understood the letter of information and signed the consent form.

All students at the 5 campuses who met the inclusion criteria were invited to participate in the research study. Participation was voluntary and no students were forced into entering the study. All students were provided with information about the study, both verbally and on an information sheet. Students who agreed to participate after reading the information letter, signed a consent form prior to answering the self-administered questionnaire.

A new questionnaire was developed, as an appropriate one was not available for the purposes of this study. The questionnaire was also used as part of a larger study. It was developed by the researcher (EML) from four common themes, in addition to a section on demographic data. The themes included: English as a second language, first-generation students, stressors experienced by students and programme orientation. There was a total of 76 questions, of which 48 were used for this part of the study. These included simple dichotomous questions for demographics, questions using rating and ranking scales and Likert scale-type questions. A combination of different types of questions increases the reliability and validity of the tool. ${ }^{[16]}$

Participants were asked to respond to statements about factors that cause stress, by selecting 1 of 5 stress levels in response to each statement. The levels of stress were scored from 1 (not at all stressful) to 5 (very stressful). Students were also asked to consider statements about factors to relieve stress and indicate their choice according to a Likert scale, from 1 (strongly disagree) to 5 (strongly agree).

After construction of the questionnaire, a focus group discussion was held to ensure validity of the questionnaire. The focus group discussion took place during the departmental research committee meeting, which comprised 6 academics, 5 of whom are also professional nurses and 1 who is not a nurse but a staff member at the Faculty of Health Sciences. This group of experts in nursing and health science education and research was invited to judge each item in the questionnaire for relevance, clarity, simplicity and ambiguity. Items that did not adequately meet these criteria were either removed from the questionnaire or adjusted until acceptable.

The post-focus group questionnaire was then piloted for reliability with 5 students who met the inclusion criteria for the study, but who were excluded from the main study. The purpose of the pilot study was to detect flaws, establish usefulness of the questions and, if necessary, amend the questions. The pilot study population indicated that they understood the questions and did not have difficulty in answering them; therefore, no changes were made to the questionnaire.
Data were collected between September and November 2013. An academic not involved in the research distributed the questionnaires and was available in the classroom to answer any queries that the students might have had. The researcher was available in a nearby room to answer any queries of respondents if necessary. She was not in the classroom, in an effort to prevent students feeling obligated to participate in the study. All participants were required to sign a consent form prior to answering the questionnaire. No students were coerced into participating.

Data were analysed on SPSS version 17 (SPSS Inc., USA) by means of frequency distribution of responses and mean scores. To test for significant trends in the data, inferential statistics were applied. These included Pearson's correlation and $\chi^{2}$ tests. Wilcoxon signed-rank tests were used for the comparison of non-parametric data. Throughout, $p<0.05$ was used to indicate significance.

\section{Ethical approval}

The study was approved by the Durban University of Technology Institutional Research Ethics Committee (ref. no. IREC 052/13). Permission to conduct the study at the nursing college was obtained from the KZN Department of Health and the acting principal of the college.

\section{Results}

\section{Participant demographics}

Of the 267 questionnaires distributed, 248 were completed, giving a response rate of $92.8 \%$. Participant demographics are indicated in Table 1.

\begin{tabular}{ll} 
Table 1. Participant demographics & \\
\hline Demographics & Participants, $\boldsymbol{n}$ (\%) \\
\hline Gender & \\
Female & $174(70.2)$ \\
Male & $74(29.8)$ \\
Age category, years & \\
19-20 & $41(16.5)$ \\
$21-22$ & $42(16.9)$ \\
$23-24$ & $48(19.4)$ \\
$24-25$ & $41(16.5)$ \\
$\geq 26$ & $75(30.2)$ \\
Race & \\
Black African & $215(86.7)$ \\
Indian & $22(8.9)$ \\
Coloured & $10(4.0)$ \\
White & $1(0.4)$ \\
Home language & $195(78.6)$ \\
isiZulu & $33(13.3)$ \\
English & $7(2.8)$ \\
isiXhosa & $1(0.4)$ \\
Afrikaans & $12(4.8)$ \\
Other African language & \\
Area raised & $152(61.3)$ \\
Rural & $96(38.7)$ \\
Urban & $115(46.4)$ \\
Type of secondary school attended & $66(26.6)$ \\
Rural government & $55(22.2)$ \\
Urban government & $12(4.8)$ \\
Peri-urban government /township \\
Private & \\
&
\end{tabular}


The majority were female $(70.2 \% ; n=174),<26$ years of age $(69.6 \% ; n=75)$, of black ethnicity $(86.7 \% ; n=215)$ and raised in a rural area $(61.3 \% ; n=152)$. Although $71 \%(n=175)$ were raised by their own parents, $22 \%$ were raised by extended family members, a social welfare home (4\%), a child-headed household (2\%) or members of the community (1\%). The type of secondary school attended varied significantly between the different participants $(p<0.001)$, with almost half having attended a rural government school $(46.4 \%)$. Many were the first in their family to attend a tertiary education institution (37.5\%; $n=93)$.

Half of the respondents indicated that they had basic necessities, such as electricity, clean water and adequate food, in their homes $(52.4 \% ; n=130)$, but that there was nothing extra available. Only a quarter $(23 \% ; n=57)$ always had the basic necessities and a little extra money available. Some did not have any basic necessities $(18.5 \% ; n=46)$ and only a few respondents $(4.4 \% ; n=11)$ always had everything that they wanted in their homes. For the duration of their nursing studies, all of the respondents had the opportunity to live in a nurses' residence $(100 \% ; n=248)$.

\section{Stressors experienced by first-year students}

Respondents were asked to consider statements relating to factors that cause stress by selecting 1 of 5 levels in response to each statement. The overall results are presented in Table 2. The levels of stress were scored from 1 (not at all stressful) to 5 (very stressful). The long working hours, financial pressures, assignments, difficulty of academic work, poor study methods, family illness and other problems at home caused considerable stress (mean $>3$; $p<0.001)$.

They were also required to contemplate the level of agreement to statements related to factors that may cause stress. These levels of agreement were scored from 1 (strongly disagree) to 5 (strongly agree). The overall results are presented in Table 3. The majority of respondents felt that they did not have enough time for their studies, that they had to work harder than their classmates and that they experienced more stress than their classmates. They also indicated that there was family pressure to pay for necessities at home and that there was insufficient money to pay for textbooks for their studies. Furthermore, stress affected their grades negatively (mean $>3 ; p<0.001)$.

The transition from secondary school to tertiary education was difficult (Table 4). Respondents felt that they did not know what was awaiting them before starting the nursing course $(n=247 ; p<0.001)$. They felt that nursing was not what they had expected $(n=246 ; p=0.038)$, and had anticipated the nursing programme to be more practical than theoretical $(n=246 ; p<0.001)$. Most respondents also expected 'nursing to be an easy practical job' $(n=246$; $p<0.001)$. However, the choice of another course at university did not take precedence over the nursing course $(n=246 ; p<0.001)$ and they were not studying nursing merely to receive a monthly salary - it was what they wanted to do $(n=246 ; p<0.001)$.

Table 2. Distribution of responses to factors that may cause stress

\begin{tabular}{|c|c|c|c|c|c|c|}
\hline \multirow[b]{2}{*}{ Stress factor } & \multicolumn{5}{|c|}{ Levels of stress } & \multirow[b]{2}{*}{ Mean } \\
\hline & $\begin{array}{l}\text { Not at all stressful, } \\
n(\%)\end{array}$ & $\begin{array}{l}\text { A little stressful, } \\
n(\%)\end{array}$ & Stressful, $n(\%)$ & Rather stressful, $\boldsymbol{n}(\%)$ & Very stressful, $n(\%)$ & \\
\hline Academic assignments & $13(5.3)$ & $65(26.4)$ & $76(30.9)$ & $38(15.5)$ & $54(22)$ & 3.22 \\
\hline Long working hours & $6(2.4)$ & $33(13.4)$ & $56(22.7)$ & $19(7.7)$ & $133(53.9)$ & 3.97 \\
\hline Difficulty of academic work & $21(8.7)$ & $55(22.7)$ & $83(34.3)$ & $28(11.6)$ & $55(22.7)$ & 3.17 \\
\hline Poor study methods & $39(16.0)$ & $51(20.9)$ & $68(27.9)$ & $26(10.7)$ & $60(24.6)$ & 3.07 \\
\hline Personal illness & $66(26.9)$ & $69(28.2)$ & $44(18.0)$ & $15(6.9)$ & $51(20.8)$ & 2.66 \\
\hline Family illness & $47(19.1)$ & $47(19.1)$ & $69(28.0)$ & $14(5.7)$ & $69(28.0)$ & 3.04 \\
\hline Other problems at home & $31(12.6)$ & $60(24.3)$ & $57(23.1)$ & $32(13.0)$ & $67(27.1)$ & 3.18 \\
\hline Living away from home & $69(28.4)$ & $59(24.3)$ & $37(15.2)$ & $19(7.8)$ & $59(24.3)$ & 2.75 \\
\hline Financial pressures & $17(6.9)$ & $42(17.0)$ & $47(19.0)$ & $15(6.1)$ & $126(51.0)$ & 3.77 \\
\hline
\end{tabular}

Table 3. Levels of agreement with regard to factors that cause stress

\begin{tabular}{|c|c|c|c|c|c|c|}
\hline Statement & $\begin{array}{l}\text { Strongly disagree, } \\
n(\%)\end{array}$ & Disagree, $n(\%)$ & $\begin{array}{l}\text { Neither agree nor } \\
\text { disagree, } n(\%)\end{array}$ & Agree, $n(\%)$ & $\begin{array}{l}\text { Strongly agree, } \\
n(\%)\end{array}$ & Mean \\
\hline $\begin{array}{l}\text { My family does not understand the time and energy } \\
\text { required for successful studies }\end{array}$ & $81(32.6)$ & $81(32.6)$ & $13(5.2)$ & $49(19.8)$ & $24(9.7)$ & 2.4 \\
\hline I have more stressors than my classmates & $20(8.1)$ & $74(29.8)$ & $44(17.7)$ & $78(31.5)$ & $32(12.9)$ & 3.1 \\
\hline $\begin{array}{l}\text { I do not have enough time in the day to complete all } \\
\text { the necessary tasks }\end{array}$ & $10(4.1)$ & $77(31.2)$ & $35(14.2)$ & $99(40.1)$ & $26(10.5)$ & 3.2 \\
\hline $\begin{array}{l}\text { I feel that I do not belong studying this nursing } \\
\text { programme }\end{array}$ & $96(38.9)$ & $100(40.5)$ & $23(9.3)$ & $19(7.7)$ & $9(3.6)$ & 2.0 \\
\hline Stress affects my grades negatively & $11(4.5)$ & $61(24.7)$ & $32(13.0)$ & $103(41.7)$ & $40(16.2)$ & 3.4 \\
\hline I have family pressure to pay for necessities at home & $30(12.1)$ & $72(29.0)$ & $18(7.3)$ & $81(32.7)$ & $47(19.0)$ & 3.2 \\
\hline I don't have enough money to pay for textbooks & $17(6.9)$ & $55(22.3)$ & $26(10.5)$ & $84(34.0)$ & $65(26.3)$ & 3.5 \\
\hline $\begin{array}{l}\text { In order to pass, I have to study longer hours than my } \\
\text { classmates }\end{array}$ & $9(3.6)$ & $47(19.0)$ & $38(15.3)$ & $91(36.7)$ & $63(25.4)$ & 3.6 \\
\hline
\end{tabular}




\section{Stress-relieving mechanisms}

A significantly large proportion of respondents played with their cell phones $(p<0.001)$ or socialised with their friends $(p<0.001)$ to alleviate stress. Eating, consumption of alcohol/partying and staying away from work were not used as stress relievers by most of the participants. The overall results for the coping mechanisms are presented in Table 5.

Respondents were asked to use a Likert rating from 1 to 5 to indicate the support that they received from specified sources, from 1 (not at all) to 5 (a great deal). A mean score was calculated. Most respondents felt that their lecturers (mean 4.17 (standard deviation (SD) 1.27); $n=246$ ), parents (4.00 (1.52); $n=241$ ) and friends (fellow nursing students) (3.78 (1.44); $n=246)$ were sources of support. To a lesser extent, respondents identified their siblings (3.22 (1.70); $n=245)$, friends from school (3.06 (1.61); $n=245)$ and close relatives (2.63 (1.63); $n=246)$ as sources of support.

\section{Discussion}

This study ascertained the factors that cause stress among first-year nursing students attending a college of nursing in SA. Our findings indicate that academic commitments, family finances and illness increase the outcome of stress. It is expected that the transition from a secondary to a tertiary level of education leads to longer hours of study and having to deal with subject material of a more difficult nature. Students entering tertiary institutions should be provided with mentoring workshops that help them to cope with these stressors. It is also recommended that implementation of intervention strategies is required in institutions to educate students on developing study skills to manage stress-related factors. Programmes that provide academic support should include academic, self-concept and motivational factors $^{[12]}$ that assist in this management. Mentoring by senior peers allows students to realise that this is part of the normal learning process and also offers guidance on dealing with these difficulties. Studying skills can be incorporated into these mentoring workshops, as the respondents indicated that their studying skills were poor, which also caused stress. Furthermore, these stressors led them to obtain poor grades. As previously pointed out, stressors related to poor college preparation and poor study skills are common. ${ }^{[11]}$

Most respondents found the long working hours very stressful and they did not have sufficient time to complete tasks related to their studies. Other reports indicate that a lack of time contributes to students feeling stressed. ${ }^{[17]}$ Curriculum planning in tertiary institutions needs to ensure that academic overload does not occur and that sufficient time is provided

Table 4. Levels of agreement with regard to orientation into tertiary education

\begin{tabular}{|c|c|c|c|c|c|c|}
\hline Statement & $\begin{array}{l}\text { Strongly disagree, } \\
n(\%)\end{array}$ & Disagree, $n(\%)$ & $\begin{array}{l}\text { Neither agree nor } \\
\text { disagree, } n(\%)\end{array}$ & Agree, $n(\%)$ & $\begin{array}{l}\text { Strongly agree, } \\
n(\%)\end{array}$ & Mean \\
\hline $\begin{array}{l}\text { I knew what I was getting into before starting the } \\
\text { nursing course }\end{array}$ & $65(26.3)$ & $69(27.9)$ & $21(8.5)$ & $60(24.3)$ & $32(13.0)$ & 2.7 \\
\hline I am studying nursing to get a monthly salary & $84(34.2)$ & $104(42.3)$ & $33(13.4)$ & $16(6.5)$ & $9(3.7)$ & 2.0 \\
\hline $\begin{array}{l}\text { I wish I had rather studied another course at } \\
\text { university }\end{array}$ & $79(32.1)$ & $86(35.0)$ & $40(16.3)$ & $26(10.6)$ & $15(6.1)$ & 2.2 \\
\hline Nursing is not what I expected it to be & $37(15.0)$ & 49 (19.9) & $23(9.4)$ & $100(40.7)$ & $37(15.0)$ & 3.2 \\
\hline $\begin{array}{l}\text { I thought nursing would be more practical; I didn't } \\
\text { know it would be so academically difficult }\end{array}$ & $18(7.3)$ & $28(11.4)$ & $18(7.3)$ & $104(42.3)$ & $78(31.7)$ & 3.8 \\
\hline I expected nursing to be an easy, practical job & $20(8.1)$ & $46(18.7)$ & $25(10.2)$ & $94(38.2)$ & $61(24.8)$ & 3.5 \\
\hline $\begin{array}{l}\text { At nursing college, the study culture is more difficult } \\
\text { than in high school }\end{array}$ & $5(2.0)$ & $30(12.2)$ & $15(6.1)$ & $122(49.4)$ & $75(30.4)$ & 3.9 \\
\hline $\begin{array}{l}\text { At nursing college, it is more difficult to achieve well } \\
\text { academically }\end{array}$ & $6(2.4)$ & $57(23.1)$ & $34(13.8)$ & $117(47.4)$ & $33(13.4)$ & 3.5 \\
\hline $\begin{array}{l}\text { At nursing college, there is a lot more work to do in } \\
\text { a short time }\end{array}$ & $1(0.4)$ & $7(2.8)$ & $9(3.6)$ & $103(41.7)$ & $127(51.4)$ & 4.4 \\
\hline $\begin{array}{l}\text { At nursing college, the method of teaching is } \\
\text { different and faster }\end{array}$ & $4(1.6)$ & $30(12.2)$ & 29 (11.7) & $113(45.8)$ & $71(28.8)$ & 3.9 \\
\hline
\end{tabular}

Table 5. Levels of agreement with regard to stress-coping mechanisms used by students

\begin{tabular}{|c|c|c|c|c|c|c|}
\hline I deal with stress by ... & $\begin{array}{l}\text { Strongly disagree, } \\
n(\%)\end{array}$ & Disagree, $n(\%)$ & $\begin{array}{l}\text { Neither agree nor } \\
\text { disagree, } n(\%)\end{array}$ & Agree, $n(\%)$ & $\begin{array}{l}\text { Strongly agree, } n \\
(\%)\end{array}$ & Mean \\
\hline Eating & $65(26.3)$ & $79(32.0)$ & $26(10.5)$ & $58(23.5)$ & $19(7.7)$ & 2.5 \\
\hline Playing on my cell phone & $27(10.9)$ & $62(25.1)$ & $26(10.5)$ & $89(36.0)$ & $43(17.4)$ & 3.2 \\
\hline Socialising with friends & $27(11.0)$ & $34(13.9)$ & $19(7.8)$ & $113(46.1)$ & $52(21.2)$ & 3.5 \\
\hline Keeping to myself & $31(12.6)$ & $77(31.3)$ & $31(12.6)$ & $64(26.0)$ & $43(17.5)$ & 3.0 \\
\hline Crying and complaining & $68(27.9)$ & $86(35.3)$ & $20(8.2)$ & $54(22.1)$ & $16(6.6)$ & 2.4 \\
\hline Drinking alcohol/partying & $144(58.8)$ & $63(25.7)$ & $17(6.9)$ & $13(5.3)$ & $8(3.3)$ & 1.7 \\
\hline Exercising & $35(14.2)$ & $52(21.1)$ & $36(14.6)$ & $82(33.2)$ & $42(17.0)$ & 3.2 \\
\hline Staying home from work & $98(39.7)$ & $85(34.4)$ & $24(9.7)$ & $29(11.7)$ & $11(4.5)$ & 2.1 \\
\hline
\end{tabular}


for the completion of tasks. Time-management workshops can alleviate such problems, particularly if these are held early in the students' first year at college. Moreover, if time is adequately managed by students, there could be an indirect improvement of their grades. Recent studies indicated that group work is beneficial to students in the health sciences, with students gaining an enhanced understanding of the subject matter when working with their peers. ${ }^{[18,19]}$ Group work may also be beneficial in time management. Brief activities or larger assignments of a collaborative nature will make learning enjoyable ${ }^{[19]}$ and hence alleviate stress.

Despite receiving a bursary of ZAR3 000 (USD214) per month for the duration of their training, finances were a source of stress. While financial stress has previously been documented, ${ }^{[10]}$ a novel finding of this study was that although students were living away from home, they felt that there was family pressure to pay for basic necessities at home. Even though their families understood the time and energy required for their studies to be successful, there was nevertheless the expectation of payment towards household expenses, as essential items are often lacking in their homes, particularly for students from rural backgrounds and of low socioeconomic status. This would be a common dilemma faced in developing countries and would be further exacerbated for first-generation students. The students also indicated that despite receiving bursaries for their studies, there was insufficient money to purchase textbooks from these funds. It is possible that these students use part of their funds for household expenses.

Some students indicated that illness experienced by family members, problems at home, personal illness, and living away from home caused stress. This, yet again, demonstrates the closely-knit families from where the students come. It may also be indicative of a constant presence of illness, which may be of a serious nature. The incidence of HIV in KZN is among the highest in the world and its impact on the health of the SA workforce has a negative effect on the motivation and performance of this workforce. ${ }^{[2,21]}$ Thus, motivation and performance of students are also affected by HIV infection of family members.

Nevertheless, students do find ways of alleviating stress; one of the most important ways is socialising with friends. This concurs with reports that social support from others lessens stress. ${ }^{[22]}$ Such social support is also correlated with academic success. ${ }^{[22]}$ However, previous reports show that first-generation students tend to isolate themselves from others, particularly academics, when stressed. ${ }^{[23]}$ Our finding that lecturers are a source of support, is therefore encouraging. It indicates that current students are more willing to adapt to the study environment, are trying to fit into the academic environment and are not shy to turn to their lecturers for support. The creation of a student-friendly environment is therefore beneficial for both the academic and social needs of students. As all the respondents were living in the student-nurse hostel, a family support system for coping with stress was absent and they therefore turned to academic staff when support was required. Institutional support groups may provide additional aid to students who have difficulty in adjusting to the university environment. Students may not understand the method of pedagogy at higher education level. Teaching strategies at tertiary level are not widely understood by students, resulting in difficulty in adapting to specific programmes. Therefore, institutional support that assists students to adjust to the tertiary environment is likely to improve completion rates.

Our findings revealed that a significant proportion of respondents redirected their attention to cell phones as a way of dealing with stress. This is another novel finding and is in contrast to reports that cell phone usage increases stress. ${ }^{[24]}$ This could possibly be related to the current use of cell phones for social networking, accessing the internet, watching and sharing of videos, as well as playing video games ${ }^{[25]}$ - in addition to the use of cell phones for making telephone calls and text messaging. The former uses could be beneficial, particularly regarding social networking, as social support helps to relieve stress. ${ }^{[22]}$ However, such use could possibly be detrimental if it occurs during lectures, as the user will be distracted, leading to less academic information being gained. A limitation of this study is that we did not enquire about the duration of cell phone usage.

Notably, very few respondents reported drinking and binge eating as stress-relieving mechanisms, which is a very encouraging finding. Previous reports show that first-generation students are less likely to use socialcoping strategies such as drinking and partying to manage their stress, ${ }^{[22]}$ which supports our findings. Mentoring programmes should reinforce these behaviours to ensure that future students do not resort to alcohol consumption. It is also promising that students used exercise as a stressrelieving mechanism.

Although this study was conducted at a college of nursing in KZN, the results can be generalised to universities in SA, as the majority of firstyear students at these tertiary institutions appear to come from similar backgrounds.

\section{Conclusion}

Our findings indicate that in addition to academic commitments, financial pressures and illness that affect the families of students are a major source of stress among first-year nursing students in SA. Students tend to socialise with friends and play with cell phones to relieve stressful situations. In addition to friends, lecturers were a source of support. We suggest that the incorporation of stress and time management into the curriculum would be beneficial to first-year nursing students. We also propose that institutional support units should be created to assist students in adjusting to the tertiary environment.

Acknowledgements. We acknowledge support from the Durban University of Technology towards EML's research project for the Master of Technology (Nursing) degree.

Author contributions. EML collected the data and wrote the first draft of the manuscript. AR and FH supervised the project, edited the manuscript and approved the final article.

Funding. Durban University of Technology funding for Masters' students. Conflicts of interest. None.

1. Council on Higher Education. A Proposal for Undergraduate Curriculum Reform in South Africa: The Case for a Flexible Curriculum Structure. Pretoria: $\mathrm{CHE}, 2013$.

. South African Nursing Council. South African Nursing Council statistics: Annual statistics. 2011. http://www sanc.co.za/stats_an.htm (accessed 12 May 2013).

3. Hopkins TH. Early identification of at-risk nursing students: A student support model. J Nurse Educ 2008;47(6):254-259. https://doi.org/10.3928/01484834-20080601-05

4. Buchan J, Aiken L. Solving nursing shortages: A common priority. J Clin Nurse 2008;17(24):3262-3268. https:// doi.org/10.1111/j.1365-2702.2008.02636.x

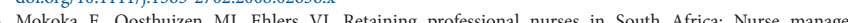
5. Mokoka E, Oosthuizen M), Ehlers VJ. Retaining professional nurses in South Africa:
perspectives. Health SA Gesondheid 2010;15(1):1-9. https://doi.org/10.4102/hsag.v15i1.484

Chikte U, Brand A. Diversity in South African dental schools. J Dent Ass S Afr 1996;51(10):641-646.

6. Chikte U, Brand A. Diversity in South African dental schools. J Dent Ass S Afr 1996;51(10):641-646.
7. Fraser WJ, Killen R. Factors influencing academic success or failure of first-year and senior university students Fraser WJ, Killen R. Factors influencing academic success or failure of first-year and senior unive
Do education students and lecturers perceive things differently? S Afr J Educ 2003;23(4):254-263.

8. Murray M. Factors affecting graduation and student dropout rates at the University of KwaZulu-Natal. S Afr J Sci 2014;110(11-12):1-6. https://doi.org/10.1590/sajs.2014/20140008

9. Stephen D, Welman J, Jordaan W. English language proficiency as an indicator of academic performance at tertiary institution. S Afr J Hum Resource Manage 2004;2(3):42-53. https://doi.org/10.4102/sajhrm.v2i3.48

10. Timmins F, Kaliszer M. Aspects of nurse education programmes that frequently cause stress to nursing student - fact-finding sample survey. Nurse Educ Today 2002;22(3):203-211. https://doi.org/10.1054/nedt.2001.0698

11. Starr K. Nursing education challenges: Students with English as an additional language. J Nurse Educ 2009;48(9):478-487. https://doi.org/10.3928/01484834-20090610-01 
12. Khalaila R. The relationship between academic self-concept, intrinsic motivation, test anxiety, and academic achievement among nursing students: Mediating and moderating effects. Nurse Educ Today 2015;35(3):432-438 https://doi.org/10.1016/j.nedt.2014.11.001

13. Clarke VA, Ruffin CL. Perceived sources of stress among student nurses. Contemp Nurse 1992:1(1):35-36. https:// doi.org/10.1080/10376178.1992.11001462

14. Lindop E. Individual stress among nurses in training: Why some leave while others stay. Nurse Educ Today 1991;11(2):110-120. https://doi.org/10.1016/0260-6917(91)90146-2

5. Turner K, McCarthy VL. Stress and anxiety among nursing students: A review of intervention strategies in literature between 2009 and 2015. Nurse Educ Pract 2017;22:21-29. https://doi.org/10.1016/j.nepr.2016.11.002

16. Burns N, Grove S. The Practice of Nursing Research: Appraisal. Synthesis and Generation of Evidence. 6th ed. St Louis: Saunders Elsevier, 2009.

17. Watkins KD, Roos V, van der Walt $\mathrm{E}$. An exploration of personal, relational and collective well-being in nursing students during their training at a tertiary education institution. Health SA Gesondheid 2011;16(1):1-10. https:/ doi.org/10.4102/hsag.v16i1.552

18. Van Wyk J, Haffejee F. Benefits of group learning as a collaborative strategy in a diverse higher education. Int Educ Sci 2017;18(1-3):158-163. https://doi.org/10.1080/09751122.2017.1305745

19. Haffejee F, van Wyk J, Hira V. Use of role-play and community engagement to teach parasitic diseases. Afr Health Professions Educ 2017:9(2):51-53. https://doi.org/10.7196/AJHPE.2017.v9i2.673
20. Nel A, Mabude Z, Smit J, et al. HIV incidence remains high in KwaZulu-Natal, South Africa: Evidence from three districts. PLOS ONE 2012;7(4):e35278. https://doi.org/10.1371/journal.pone.0035278

. Tawfik L, Kinoti SN. The Impact of HIV/AIDS on the Health Workforce in Developing Countries. Geneva: Worl Health Organization, 2006

22. Mehta SS, Newbold JJ, O’Rourke MA. Why do first-generation students fail? Coll Student J 2011;45(1).

23. Paulynice R. What causes many college students to fail or drop out? 2011. https://hubpages.com/education/ What-Causes-College-Students-to-Fail-or-Dropout\#comment8223407 (accessed 6 August 2013).

24. Thomée S, Härenstam A, Hagberg M. Mobile phone use and stress, sleep disturbances, and symptoms of depression among young adults - a prospective cohort study. BMC Public Health 2011:11(1):66. https://dol. org/10.1186/1471-2458-11-66

25. Lepp A, Barkley JE, Karpinski AC. The relationship between cell phone use, academic performance, anxiety, and satisfaction with life in college students. Compute Hum Behav 2014;31:343-350. https://doi.org/10.1016/j. chb.2013.10.049

Accepted 12 October 2017 